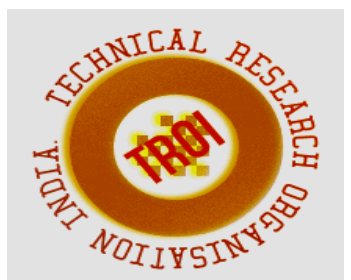

\title{
COMPRESSIVE STRENGTH OF FLY ASH BRICKS WITH ADDITION OF BAGASSE ASH
}

M Maneela ${ }^{1}$ Dr. Syed Ariff ${ }^{2}$ Mahesh $\mathrm{P}^{3}$, Rashmi G V ${ }^{4}$, Manohar $\mathbf{M}^{5}$, Srinivasa ${ }^{6}$

Department of Civil Engineering, Kolar Gold Fields, Karnataka.

${ }^{1}$ Associate Professor \& HOD, Dr.T.Thimmaiah Institute of Technology, KGF.

${ }^{2}$ Professor \& Principal, Dr.T.Thimmaiah Institute of Technology, KGF.

${ }^{3,4,5,6}$ Final year UG Students, Dr.T.Thimmaiah Institute of Technology, KGF.

E Mail Id: hod.civ@drttit.edu.in,principal @drttit.edu.in

\section{Abstract}

The present study is to manufacture fly ash bricks with the addition of two waste materials i.e. Sugarcane bagasse ash and Quarry dust. In India population is increasing day by day and large quantity of waste is generated through many industries and agriculture which creates health hazards, disposal of this waste has become a major problem. Sugarcane bagasse is one among it which is produced due to burning of bagasse ash. In order to use waste material effectively we used bagasse ash in preparation of fly ash bricks in different proportions i.e. $10 \%-50 \%$.Trial bricks of size $(150 * 150 * 150 \mathrm{~mm})$ are prepared and the tests carried out are Water absorption and Compressive strength as per Indian standards.The present study carried out is to explore the potential of using bagasse ash in brick production. The outcome of this work indicates the maximum compressive strength obtained for optimal mix percentage .Henceforth we can conclude that addition of waste material in manufacturing of brick can minimize the environmental burden leading towards cost effective and green construction. Keywords: Cement, Quarry Dust, Fly Ash, Sugar cane bagasse ash[SCBA],Lime and Compressive strength

\section{INTRODUCTION}

In India there is a substantial increase in population due to increase in industries which leads to production of approximately 250 to 300 million tons of industry waste. It is very necessary to abandon this waste safely without affecting public health, environment and fertilize land. Therefore an attempt is made to reuse the sugarcane

Bagasse ash in the preparation of bricks in different proportions to calculate its compressive strength after 7 days, 14 days and 28 days. Based on the result the suitability of bagasse ash in different structural elements has been decided.

\section{OBJECTIVES}

The main objective of this work is to study the effect of addition of Bagasse ash in manufacture of fly ash bricks and to protect the environment by effective disposal of Bagasse ash.

\section{LITERATURE REVIEW}

Mirtyunjay Kumar, Shivani Singh Dhriyan [ 2017] concluded that 10 t0 20\% of cement can be partially replaced by SCBA for higher strength, flexural strength and tensile strength .By addition of SCBA concrete had become more durable and requirement of super plasticizer is not needed. SCBA concrete mixture show good modulus of elasticity.ManishCCetroja [2018] demonstrated that addition of bagasse ash more than $20 \%$ causes more water absorption, reduction in compressive strength less hardness under burnt.so he recommended that upto 20 to $25 \%$ bagasse ash can be replaced by clay in bricks.Kishore ,S.Kotteswaran concluded that 
bagasse ash can be added upto $50 \%$,further little addition of bagasse ash starts the formation of crack .

\section{EXPERIMENTAL MATERIALS}

\subsection{Fly ash}

Fly ash is a fine grey powder consisting mostly of spherical, glassy particles that are produced as a byproduct in coal-fired power stations. When flyash is combined with lime cementitious compounds are formed and it exerts pozzolanic properties. It is commonly known as a supplementary cementitious material.. Fly ash is a composite material.

Fly ash is suitable for a wide variety of applications and uses, including Concrete Dams ,Flowable fills, Mines,Landfills and Geopolymer concreteFly ash is also known as flue-ash or simply ash.

The main chemical components present in fly ash are:

\begin{tabular}{|c|c|c|}
\hline S.No & Chemical Compound & Percentage(\%) \\
\hline 1. & $\mathrm{SiO} 2$ & 5.39 \\
\hline 2. & $\mathrm{Fe} 2 \mathrm{O} 3$ & 0.39 \\
\hline 3. & $\mathrm{Al} 2 \mathrm{O} 3$ & 1.06 \\
\hline 4. & $\mathrm{CaO}$ & 28.60 \\
\hline 5. & $\mathrm{Mgo}$ & 2.42 \\
\hline 6. & $\mathrm{SO} 2$ & 0.93 \\
\hline
\end{tabular}

Fly ash is suitable for a wide variety of applications and uses, including Concrete Dams ,Flowable fills, Mines,Landfills and Geopolymer concreteFly ash is also known as flue-ash or simply ash.

\subsection{Bagasse ash}

Sugarcane stalks also called as sorghum stalks are being crushed in order to obtain sugarcane juice which produces a dry pulpy residue which is fibrous. To generate electricity, heat \& energy biofuel used is bagasse. Bagasse products are perfect alternatives to petroleum based Styrofoam \& plastic products.. Bagasse products may be more likely to lose strength after a certain period of time.

\subsection{Acetyline Carbide Lime}

Huge amounts of industrial waste are generated around the world. This waste can be harmful to the environment if not disposed properly, or the disposal of the same could lead to very high costs. On the other hand, utilizing industrial waste as secondary raw materials for other industries could not only reduce costs and save the planet, but also serve as a supplementary source of income. Since lime is used in several industries, lime slurry can be treated and used in many applications.

In the process of production of acetylene , carbide and water are blended together to produce acetylene, heat and carbide lime or lime slurry. The products obtained finally are suspended in water. Thus, when calcium hydroxide mixes with water, it produces CLW .Once, the water is evaporated or dried, the lime slurry produced is in solid form. This makes disposal tedious and expensive. Hence, utilization of lime slurry in other industrial applications has proved to be beneficial for both the suppliers and users

1.3 Quarry dust It is a material originated when a rock is subjected to crushing process. As the sources of sand have been reduced there is a need to identify an alternative construction material which can be durable and stronger when compared to regular materials of concrete. It can be used as substitute to sand wholly or partly Quarry dust offers good strength when compared to sand with addition or without addition of concrete admixtures.

\section{MATERIAL COST AND COLLECTED AREA}

\subsection{Material cost :}

Bagasse ash - Rs.0.33/Kg

Fly ash - Rs.0.33/Kg

Lime- Rs.0.33/Kg

Quarry dust- Rs.0.33/Kg

\subsection{Collected area:}

Bagasse ash - Sugarmill,KGF

Fly ash- Prakash fly ash bricks company,

Bangarpet

Lime-Lime dealor,KGF

Quarry dust- Prakash fly ash bricks 
company ,Bangarpet

\section{MIX DESIGN}

The mix design was prepared for different proportions.Total five samples have been prepared keeping lime and quarry dust as $10 \%$ constant whereas Fly ash is replaced from 50\% to $30 \%$ and bagasse ash from $10 \%$ to $50 \%$.The bonding agent used in the present study is lime.

Table 1 : Effective replacement of Flyash by bagasse ash

\begin{tabular}{|c|c|c|c|c|c|}
\hline $\begin{array}{c}\text { S. } \\
\text { No }\end{array}$ & Sample & $\begin{array}{c}\text { Bagas } \\
\text { se } \\
\text { ash(\% } \\
\text { ) }\end{array}$ & $\begin{array}{c}\text { FlyA } \\
\text { sh(\% } \\
\text { ) }\end{array}$ & $\begin{array}{c}\text { Quar } \\
\text { ry } \\
\text { dust( } \\
\%)\end{array}$ & $\begin{array}{c}\text { Lime } \\
(\%)\end{array}$ \\
\hline 1 & Std & 10 & 50 & 20 & 20 \\
\hline 2 & S1 & 10 & 70 & 10 & 10 \\
\hline 3 & S2 & 20 & 60 & 10 & 10 \\
\hline 4 & S3 & 30 & 50 & 10 & 10 \\
\hline 5 & S4 & 40 & 40 & 10 & 10 \\
\hline 6 & S5 & 50 & 30 & 10 & 10 \\
\hline
\end{tabular}

\section{EXPERIMENTAL METHODOLOGY}

4.1 Manufacturing process

The manufacturing process consists of four following methods.

- Batching

- Mixing

- Handling \& pressing of the mix

- Curing

\subsection{Test for Bricks}

The following are the tests done for bricks

1. Compression test

2. Water absorption test

Compression Test: This test is done to determine the compressive strength of bricks. It can be calculated by using the formula

Compressive strength=(Maximum load at failure(N))/(Area of the specimen $\left(\mathrm{mm}^{2}\right)$ )

Water Absorption Test: This test is done to know the quality of brick by observing the percentage of water it absorbs. It can be calculated by using the formula
Water absorption $=((\mathrm{W} 2-\mathrm{W} 1) / \mathrm{W} 1) * 100$

Where W1 = Dry weight of brick in kg

W2 = Dry weight of brick in kg

\section{RESULTS AND DISCUSSIONS}

\subsection{Compressive strength results}

Table shows the weight, density and compressive strength of different samples based on the result we can conclude that the sample (S1) which contains $70 \%$ vof fly ash, $10 \%$ of bagasse ash , $10 \%$ of lime and $10 \%$ of quarry dust gives maximum strength

Table 2 : Compressive Strength Values of SCBA Bricks for 7 days and 14 days

\begin{tabular}{|c|c|c|c|}
\hline $\begin{array}{l}\mathrm{S} . \\
\mathrm{N}\end{array}$ & Sample & $\begin{array}{l}\text { Compressive } \\
\text { Strength } \\
\text { (N/mm2) }\end{array}$ & $\begin{array}{c}\text { Compressive } \\
\text { strength } \\
\text { (N/mm2) }\end{array}$ \\
\hline & & 7 days & 14 days \\
\hline 1. & Std & 4.5 & 5.7 \\
\hline 2. & S1 & 7.2 & 7.7 \\
\hline 3. & S2 & 7.4 & 7.9 \\
\hline 4. & S3 & 6.7 & 7.2 \\
\hline 5. & $\mathrm{~S} 4$ & 4.8 & 5.5 \\
\hline 6 & S5 & 4.3 & 5.3 \\
\hline & & & ength \\
\hline
\end{tabular}

$\mathbf{N} / \mathbf{m m}^{2}$

\section{Compressive Strength values for Various Mix Proportions}

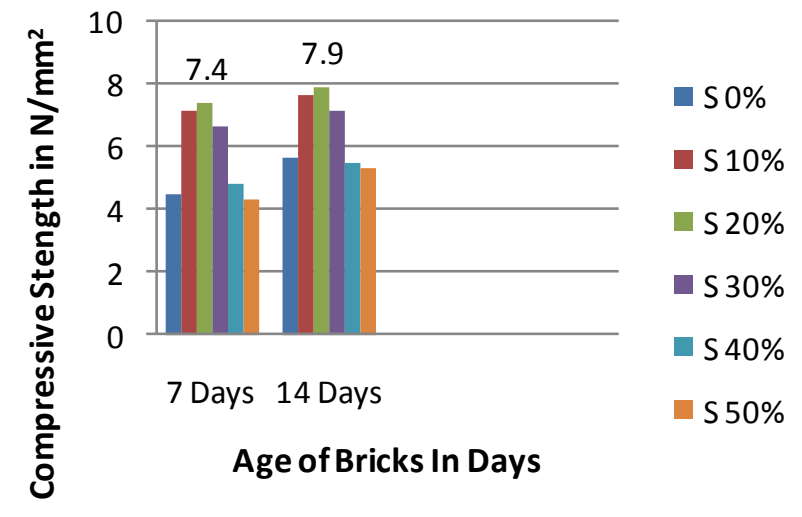




\subsection{Water absorption results}

Table 3 includes dry weight, wet weight, density and water absorption ratio. From the result we can conclude that water absorption is not exceeding $20 \%$ and is ranging between 8 to $20 \%$.

Table 3 : Results for water absorption test for 7 days and 28 days

\begin{tabular}{|c|c|c|c|c|}
\hline S.No & Sample & $\begin{array}{c}\text { Dry } \\
\text { Weight } \\
\text { (W1) } \\
\text { (kg) }\end{array}$ & $\begin{array}{c}\text { Wet } \\
\text { Weight } \\
\text { (W2) } \\
\text { (kg) }\end{array}$ & $\begin{array}{c}\text { Water } \\
\text { Absorption } \\
\text { Value } \\
(\%)\end{array}$ \\
\hline 1. & Std & 3.16 & 3.42 & 8.22 \\
\hline 2. & S1 & 3.15 & 3.52 & 11.7 \\
\hline 3. & S2 & 3.17 & 3.47 & 9.46 \\
\hline 4. & S3 & 2.98 & 3.30 & 10.73 \\
\hline 5. & S4 & 2.88 & 3.37 & 17.0 \\
\hline 6. & S5 & 2.82 & 3.28 & 16.31 \\
\hline
\end{tabular}

Water absorption $=9.46 \quad \%$

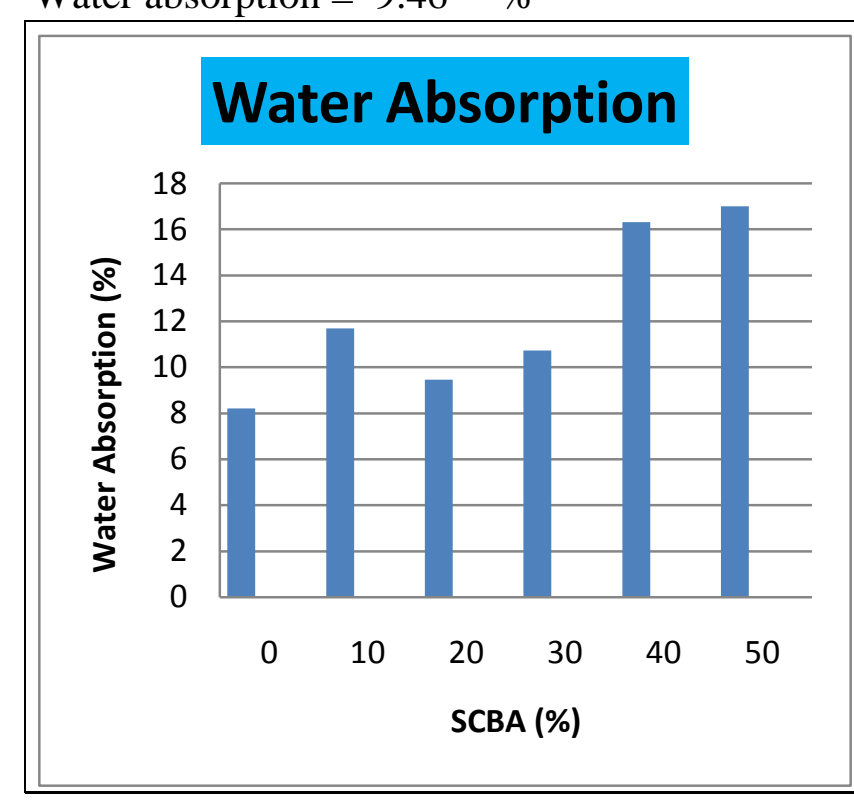

5.3 Comparison between fly ash brick and bagasse ash bricks
TABLE 4 : Difference between flyash brick and bagasse ash brick

\begin{tabular}{|c|c|c|c|c|}
\hline $\begin{array}{l}\text { S. } \\
\text { No }\end{array}$ & $\begin{array}{c}\text { Descriptio } \\
n\end{array}$ & $\begin{array}{c}\text { Fly ash } \\
\text { bricks }\end{array}$ & $\begin{array}{c}\text { Bagasse } \\
\text { ash } \\
\text { bricks }\end{array}$ & Remarks \\
\hline 1. & Size & $\begin{array}{l}230 * 1 \\
00 * 90\end{array}$ & $\begin{array}{c}230 * 100 \\
* 90\end{array}$ & - \\
\hline 2. & $\begin{array}{l}\text { Volume } \\
\text { (cm3) }\end{array}$ & 1200 & 1200 & - \\
\hline 3. & $\begin{array}{l}\text { Density } \\
\text { (Kg/m3) }\end{array}$ & 1600 & $\begin{array}{c}1300- \\
1600\end{array}$ & $\begin{array}{c}\begin{array}{c}\text { Higher load } \\
\text { bearing }\end{array} \\
\end{array}$ \\
\hline 4. & $\begin{array}{c}\text { Water } \\
\text { absorption } \\
(\%)\end{array}$ & $\begin{array}{c}15-25 \\
\%\end{array}$ & $5-17 \%$ & $\begin{array}{c}\text { Less } \\
\text { Dampness }\end{array}$ \\
\hline 5. & $\begin{array}{l}\text { Compressi } \\
\text { ve } \\
\text { Strength } \\
\left(\mathrm{N} / \mathrm{mm}^{2}\right)\end{array}$ & $3.5-10$ & $3-8$ & $\begin{array}{c}\text { Higher } \\
\text { load } \\
\text { bearing }\end{array}$ \\
\hline 6. & Price & $\begin{array}{c}3.5-4 \\
\text { Rs }\end{array}$ & $\begin{array}{c}1.82-2.5 \\
4 \mathrm{Rs}\end{array}$ & $\begin{array}{c}\text { Less } \\
\text { in cost }\end{array}$ \\
\hline 7. & $\begin{array}{l}\text { Manufactu } \\
\text { ring time }\end{array}$ & $\begin{array}{c}2-3 \\
\text { month } \\
\mathrm{s}\end{array}$ & 3-5 days & $\begin{array}{c}\text { Takes less } \\
\text { Time }\end{array}$ \\
\hline 8 & Pollution & Yes & $\begin{array}{c}\text { No } \\
\text { pollutio } \\
n\end{array}$ & Eco friendly \\
\hline
\end{tabular}

\section{CONCLUSIONS}

In the present study bagasse ash is partially replaced in place of fly ash in the manufacturing of fly ash bricks and different tests were carried out to find out the efficiency of the brick. From the table it is noted that $20 \%$ replacement of bagasse ash gives maximum compressive strength when compared to $40 \%$ \& $50 \%$ replacement.

With the replacement of $20 \%$ of bagasse ash there is good bonding between particles and no cracks are formed. With the further increase i.e. $30 \%$ slight cracks are occurs which is clearly indicated in figure. Even if the brick is properly mixed and prepared well there is no binding property and also change in volume of the brick occurs with the addition of $40 \%$ of bagasse ash. When $50 \%$ of bagasse ash is added there is no bonding indicating failure of the specimen. 
Finally we can conclude that there is an decrease in compressive strength due to increase in bagasse ash from 30\%

\section{REFERENCES}

1.G.Viruthagiri,S.Sathiya priya,N.Shanmugam euse of Sugarcane Bagasse Ash for clay brick production" Volume 4 Issue 8 August 2014 ISSN-2249-555X.

2..Surya Bhushan Singh ,Ayush Bhartdwaj "Use of sugarcane bagasse ash as brick material “ IJSRD Vol 4 Issue 06,2016.
3.D.Kishore,S.Kotteswaran "Review on bagasse ash an an effective replacement in fly ash bricks" IRJET Volume 5 Issue 06 June 2018.

4.Mrityunjay kumar ShivaniSingh Dhriyan"Review on effect of bagasse ash on strength of concrete"IJERTISSN:2278-0181 volume 7 issue 01,2018

5.Manish C Detroja “Bagasse ash brick”IJARIIE -ISSN (O)-2395-4396 vol 4 issur 42018

6.M.S.Shetty Concrete Technology Text book first edition. 